\title{
Same Size Doesn't Fit All: Insights from research on listening skills at the University of the South Pacific (USP)
}

\author{
Rajni K. Chand \\ University of Otago, New Zealand
}

\begin{abstract}
Listening skills research has tended to focus on strategy use in classrooms and on theory and practice of second language (L2) teachers. This study examined the teachers' and learners' perceptions of listening skills in non-classroom learning situations. Five $(n=5)$ study skills teachers and 19 former learners in a distance study skills course at the University of the South Pacific (USP) were interviewed for this study. The interviews with the study skills teachers sought their expectations of their learners' listening strategies, their views about the learners they taught, and the skills their learners used for listening. Former learners were similarly questioned about their perceptions of listening strategies they were taught and used. Data was collected and managed using NVivo, a computer assisted qualitative data analysis software. Besides revealing strategies that distance learners reported using their learning listening skills, the study identified a number of differences in views presented by researchers and L2 teachers, as well as differences in perceptions on listening skills between L2 teachers and L2 learners. The paper concludes that there exists a discrepancy between research and the practice of researchers, L2 teachers, and L2 learners on what works. The author also recommends further research in this area is needed, because research examining classroom-based learning situations will likely not apply to, nor fully inform, distance learning contexts.
\end{abstract}

Keywords: Distance learning; listening strategies; University of the South Pacific (USP); learning strategies; learner perceptions; teacher perceptions

\section{Introduction}

This paper aims to shed light on learners' and teachers' perceptions of language learning strategies (LLS) used for listening skills. It does so by using findings from a recent study conducted at University of the South Pacific (USP), which sought to examine the 'listening needs' of distance students for most of whom English is a second language.

The larger project collected views from four groups at USP: former and present students enrolled in a study skills course offered at a distance by USP, study skills teachers who taught the course, and course teachers taking distance courses. Other forms of data collection included questionnaires which were distributed to two groups of learners and course material analysis. The focus of this paper will be on the former learners' and teachers' perceptions of the students' 
Same Size Doesn't Fit All: Insights from research on listening skills at the University of the South Pacific (USP) Chand

listening skills, and specifically the differences reported by these two groups. Additionally, this paper aims to compare the findings with research by Berne $(1995,1996,1998)$ and reviews by Mendelsohn (2001a, 2001b), which show that teachers rarely refer to studies conducted on listening to inform their practice, and that they tend not to spell-out the strategies they want students to use in their classrooms.

This paper first provides readers with the current theoretical background on listening skills, language learning strategies, learners' and teachers' perceptions of language learning strategies, and the researchers' views on classroom practices. Next, the background to the study is presented, which includes participant details, and data collection methods and analysis used. This will be followed by discussion of the results, conclusion, limitations of the study, and possible directions for future research.

\section{Theoretical Background}

Listening plays an important role in language learning (Anderson \& Lynch, 1988; Dunkel, 1991; Rost, 1990; Rubin, 1994) and is possibly the most essential language skill (Oxford, 1993). It is also "the least explicit of the four language skills" (Vandergrift, 2004, p. 1) - speaking, listening, reading and writing: the four academic skills - because it is the most difficult to observe. Research on 'listening' began with Rankin (1930) who found listening to be the most frequently used mode of communication amongst humans. According to Brown (1987), research on listening as a field of inquiry began in the 1940s with the pioneering work of Nichols, who initiated the change to a communication programme with the encouragement of the National Council of Teachers of English in the United States. From the 1950s until the late 1970s, studies of listening focussed on the pedagogical and assessment aspects of listening, such as listening comprehension and critical listening (Feyten, 1991). Since the 1980s, studies related to listening strategies began to emerge. Early studies on language learning and listening strategies are discussed by O'Malley and Chamot (1989), Oxford (1990), and Rubin and Thompson (1994).

Foreshadowing the research findings of this study, language learning strategies are also of importance in learning study skills. According to Chamot (2005), learning strategies are procedures that facilitate learning and are conscious and goal-driven. Examining students' learning strategies can help gain insight into the metacognitive, cognitive, social, and affective strategies used by second language (L2) students. Less successful students can be taught strategies to help them become better language learners (Chamot, 2005, p. 112). Studies of language learning strategies began in the1970s with the work of Rubin (1975) and Stern (1975), who reported on the strategies used by successful L2 learners. Other studies followed that looked at student characteristics and strategic techniques used for effective language learning (O'Malley \& Chamot, 1990; O’Malley, Chamot, Manzanzres, Kupper \& Russo, 1985; Takeuchi, 2003). Studies of less successful students showed that, like their more successful student counterparts, they too used learning strategies frequently, but in a less effective manner (Chamot \& El-Dinary, 1999; Khaldieh, 2000; Vandergrift, 1997a, 1997b, 2003). A number of other factors such as the concept of 'will' (Leontiev, 1981), 'learning stamina' (Strevens, 1978), and 'learner persistence' (Schumann, 1980) were also claimed to be affecting second language acquisition.

According to Mendelsohn (2001a) and Berne (1998), however, studies on listening skills have not yet reached the classroom, and research has yet to be conducted in the classroom. Even after nearly a decade, studies on listening skills remains limited. Teachers rarely refer to studies

conducted on listening to inform their practice. Moreover, teachers typically do not spell out the strategies or the expectations that they expect from their students. Indeed, both Berne (1996, 
1998) and Mendelsohn (2001a) discuss the mismatch between the researchers' focus and actual classroom practice on listening skills. Berne's (1996) study, for instance, compares the questions addressed by second language (L2) researchers and those addressed by classroom instructors. Berne's study reveals limited overlap between issues that interested both the researchers and the classroom instructors. Berne (1996) reviewed studies conducted on L2 listening, and she interviewed nine language instructors. Her study shows that classroom instructors seldom, if ever, refer to 'listening research' to inform their practice, because the research did not provide answers to their questions, such as the effectiveness of different types of activities, and the relationship between listening and other skills. Similarly, Mendelsohn (2001b) discusses the differences between the researchers' and the teachers' research agendas. Teachers have issues that arise from the observations they make from their classroom experiences, while researchers usually focus on issues they find interesting and feel are worth investigating. This gap in the research agenda, according to Mendelsohn (2001b), can be bridged if teachers themselves undertake classroombased research, or when researchers teach in classrooms for a while and can fully appreciate what is really at issue in the classroom.

Related to research in the classroom, Griffiths and Parr (2001), Nunan (1986), Hawkey (2006), and O'Malley et al. (1985) examine the differences between language learners' and teachers' perceptions of language learning, and what actually is happening in the classroom. Griffiths and Parr (2001) discuss a study that showed parallel results to that of Nunan's (1986) study. Like Nunan's research, the Griffiths and Parr study which examined students' and teachers' perceptions of language learning strategies used, revealed discrepancies between students' and teachers' perceptions. While teachers believed that the students used memory strategies the most and were less reliant on cognitive strategies, students, on the other hand, reported that they primarily used social strategies and memory strategies the least - the exact opposite of what teachers believed they used.

Nunan $(1986,2000)$ also discussed the mismatch between teachers' and learners' expectations of the classroom. Using interviews and classroom observation as research tools, Nunan probed teachers' perceptions of what they felt is important in the learning process. While teachers believed in using communicative oriented activities, students, on the other hand, were found to value traditional learning activities more. Of the 10 learning activities researched by Nunan, only one (i.e., conversation) was selected by both teachers and students as important in the learning process.

Hawkey's (2006) study, which employed quantitative and qualitative data collection methods, also found differences between teachers' and students' perceptions of activities that took place in their classrooms. While both groups agreed on the importance of communicative approaches for language learning, both the teachers and students reported differences in the way they perceived grammar and pair work in their classes.

O'Malley and colleagues (1985) similarly found differences between teachers' beliefs on students' use of language learning strategies in the classroom versus students' perception of language learning strategies used. While students reported using a variety of language learning strategies, teachers "were generally unaware of their students' strategies" (p.20).

The recognition of the importance of language learning strategies began in 1975, and since then various frameworks to examine learners' reported language learning strategies have been designed. Oxford's (1990) Strategy Inventory for Language Learning, and O'Malley and colleagues' (1985) list of language learning strategies are two such frameworks. This study uses 
the description of language learning strategies put forth by O'Malley and colleagues (1985) and adapts it for discussing listening strategies in this paper.

Insights from research and views expressed by Berne (1996), Griffiths and Parr (2001), Hawkey (2006), Mendelsohn (2001a), Nunan (1986), and O’Malley and colleagues (1985) support the points expressed earlier - that a discrepancy does exist between research and actual practice in the classroom. The next section provides the background of the study reported in this paper.

\section{Background of the Study}

USP serves a region of approximately 33 million square kilometres (Bolabola \& Wah, 1995, p. 2) and spans five time zones. The countries served by USP range from the small coral atolls of Kiribati, Marshall Islands, Tokelau and Tuvalu, to the single island countries of Nauru and Niue, and volcanic groups of islands of Fiji, Solomon Islands, Vanuatu, and Samoa (Bolabola \& Wah, 1995) (see Appendix A for a map of the USP region). USP also serves a multicultural region, which can roughly be divided into three major, though often overlapping, ethnic groups. The Micronesia group of the North Pacific, the Melanesian group of the west, and the Polynesian group of the east, which altogether represent about 60 cultures and 235 languages. USP students either study full time at its main campus in Suva, Fiji, or they enrol in courses in the distance mode, which are administered from any one of 15 centres (Fiji has three centres; and Vanuatu two). Most USP programmes are offered by distance. In some cases, however, learners must travel to the campus in Suva to complete their studies.

Students who enrol in distance courses offered by USP's regional centres typically take courses that are primarily print-based, with student support offered from satellite, centre-based and/ or via visiting tutorials offered closer to the students' place of residence. Students enrolled in courses offered at a distance use their closest tutorial centre to interact with their course tutors and lecturers. Thus for most USP students studying at a distance their actual 'learning' takes place in typically remote and primarily asynchronous environments. Some courses, such as law courses for instance, require students to have an Internet connection to access the online material. And although other courses do not specify per say, it is generally expected that students have at their disposal the facilities and resources they need to complete their course-related work (i.e., a place to study, etc.). All learners enrolled in USP's certificate, diploma, and degree programmes are expected to enrol in a 'study skills course'. Moreover, the study skills course must be taken early on and concurrently with their programme of study. Thus, student enrolled for USP distance courses have at their disposal the study facilities provided by USP's centres, or they can study independently using print-based course materials. This, however, clearly indicates an imbalance in how USP's various facilities are used by students enrolled in the exact same course. In sum, some students use the facilities, while others rarely, if ever, use the facilities.

USP, however, expects its students to acquire the basic skills to cope with the academic demands of tertiary education via enrolment in its study skills course. The listening skills component of USP's study skills course - which is the focus of this report - is taught using learning materials comprised of course books and audio-taped materials. Centre-based and the satellite tutorials are held every three weeks during the semester; attendance at these tutorials is not compulsory however (see Appendix B for the study schedule for the study skills course).

The listening skills section of USP's study skills course, which comprises approximately three weeks of the semester, is designed so that students must listen to segments of two audiotapes 
(with or without pre-listening activities), after which they are given questions to test their understanding of what was said on these audio-tapes.

The first listening activity takes place in week 5 (Unit 5) of the semester. In this activity, students are expected to listen to a tape recording of a USP lecturer discussing an article in the course materials; the lecturer takes the students through the article paragraph by paragraph. This is a reading and interpreting text activity. There is also a reflective exercise wherein students are asked to predict and evaluate information in this article.

In week 11 (Unit 9) of the semester, students are provided with videos on seminar presentations. To access and watch these videos, however, students must travel to USP's centre libraries; these videos primarily contain information on their seminar presentations.

During final listening activity, which takes place in week 12 (Unit 10), students were asked to listen to Tape 2, containing recordings of two lectures. While listening to these lectures, learners are asked to practice note taking and pay close attention to transitional words, or signals. Students are also given pre- and post-listening activities based on these lectures.

Solutions are provided at the back of the course books for all these listening activities. There are no course assignments or grading, however, to test students' comprehension of the listening component of USP's study skills course. The students, however, are expected to submit an audiotaped seminar presentation for assessment as part of their coursework.

The teachers teaching the study skills are based at various USP regional centres. These teachers either had to travel to remote locations to conduct their tutorials; or the students themselves travelled to their closest centre, where the teachers conduct weekly tutorials. All the teachers interviewed were L2 teachers, and all reported that they were aware of technical facilities and learning opportunities offered by USP. Although USP's students were expected to use these centres and take part in the opportunities offered by the University, not all students, however, used these facilities, citing distance as a primary deterrent. With these differences in mind, this study aimed to investigate the teachers' and students' perceptions of the training opportunities offered to students to further develop their listening skills needed to successfully engage in higher education. The following questions served as a guide for the study:

1. What are the study skills teachers' expectations in terms of students' listening strategies?

2. What are the students' perceptions of listening strategies imparted in the distance study skills course offered by USP?

3. How are students' listening strategies and their teachers' expectations of students' listening strategies interrelated?

4. What is the role of distance study skills course at USP, and how successful is this course in fulfilling the listening needs of its students?

\section{Participants}

Five $(n=5)$ study skills teachers from various USP campuses and centres and 19 former learners, formed the sample of this study. Other interviews conducted with current students enrolled in the study skills course and course teachers, together with questionnaires and course material analysis, 
became part of the larger study mentioned in the introduction of this paper; this information, however, is not reported here (see Appendix $\mathrm{C}$ for details of the teachers and learners selected for interview).

Letters were sent to all the centre directors informing them of the larger project. The sample $(n=$ 5 teachers; $n=19$ learners) were contacted, with the assistance of the directors and study skills teachers based at the centres. Pre-set interview days were selected to coincide with the distance course tutorial dates. All 19 learners had completed the study skills course at a distance. Two $(n=$ 2) learners had studied at home in isolation and were solely dependent on the print and tapes provided in the course materials. The remainder of the students $(n=17)$ had either attended the satellite tutorials, or had face-to-face contact with their tutors at the centre-based tutorials offered by USP.

\section{Data Management and Analysis}

Data for the study was collected between July and August 2005 during visits to three centres of USP and at its Suva campus. The interviews, 30 to 45 minutes in duration, were conducted and transcribed by the researcher. All interviews were semi-structured and all began by obtaining participants' background and educational details. The second section of the interview dealt with the questions related to listening skills, such as:

- The participants' understanding of 'listening skills'.

- The strategies students used for listening and for overcoming listening difficulties encountered.

- The strategies study skills teachers used to encourage their students to use for listening.

- Students' and teachers' perception of their grasp, difficulties, and experiences of attending to the listening skills component of USP's study skills course offered at a distance.

All interviews were tape-recorded, transcribed, and coded. The research methodology used was similar to that of grounded theory (Glaser \& Strauss, 1967), which was deemed useful by the author as this method allows the "researcher to develop a theoretical account of the general features of a topic, while simultaneously grounding the account in empirical observations or data" (Martin \& Turner, 1986, p. 141). This approach was determined to be particularly useful because to date there seems to have been no research carried out examining teaching listening skills to L2 learners studying at a distance. Data collection, coding, and analysis proceeded recursively, beginning with the early stages of research being open-ended and becoming more directed with each emerging concept. The concepts were organised by recurring themes, which then became part of a set of categories that linked a number of concepts. Axial coding (Strauss \& Corbin, 1977) was employed to define the connections between subcategories, which, in turn, were used to construct a comprehensive scheme. The interview transcripts were then re-examined and recoded using this scheme to determine the set of categories and concepts to cover as much of the data as possible. NVivo, a computer assisted qualitative data analysis software programme, was used to highlight specific words and phrases that formed part of the concepts or themes. A list of all concepts or themes and subcategories, together with their occurrences in the transcripts, was subsequently created. This approach is similar to the traditional copy and paste procedure of data coding, but takes less time and saves making multiple copies of transcripts. 
Same Size Doesn't Fit All: Insights from research on listening skills at the University of the South Pacific (USP)

Chand

\section{Findings}

The themes that emerged from the interviews showed a mismatch between views expressed by the teachers versus that of the students. The remainder of this paper, therefore, will discuss these themes within the context of the theoretical insights expressed by Berne (1996), Mendelsohn (2001a, 2001b), and discrepancies on language learning strategies as explored by Griffiths and Parr (2001), Nunan (1986) and O’Malley and colleagues (1985).

This paper will focus first on the views of the teachers, followed by that of the students. All names reported are pseudonyms and all quotation(s) are verbatim unless otherwise indicated. The interviewee's pseudonym and the date the interview took place follow each interview quote.

\section{Views of the Study Skills Teachers}

The themes that emerged are: 1) the study skills teachers' listening skills expectations from the students; 2) the use of listening skills in the course; 3 ) the support they gave to their students in terms of building listening skills; 4) their views on distance teaching at USP; and 4) the impact of accent and the academic levels of students.

\section{Listening Skills Expectations}

During the interviews, the study skills teachers talked about what listening skills they anticipated to develop in their students. According to the teachers interviewed, students were expected to comprehend basic written/ read and spoken/ heard information while taking the course. "I think the learners should be able to get things at the same time as they are listening" (Judy, 3/08/2005). Similarly, Morgan expected his students to bring comprehension skills to the course. "They should be able to comprehend - that is very important because without that ability to comprehend we will not be able to listen well - and secondly, they have to be attentive" (Morgan, 6/08/2005).

Apart from expecting basic listening comprehension skills from their students, the study skills teachers expected them to have basic listening skills in order to learn what was being taught in the course. "I think they should first of all be able listen, have that capacity to be able to listen to a 50-minute lecture, or a one hour lecture" (Sahil, 27/07/2005).

Hence, the teachers indicated that the students needed to bring with them basic skills - that is comprehension, interest, and a willingness to learn, prior to taking the course - all basic skills from which students need to build upon and develop higher level listening skills demanded of tertiary studies.

\section{Listening Skills in Study Skills Course}

During the interviews, the teachers interviewed talked about the amount of time they spent teaching listening skills to their students. Since all tutorials at the centres were only held once a week and were only one hour long, all the teachers interviewed unanimously cited 'time limitations' as a major factor that impeded their ability to teach.

Not so much emphasis on listening though I would say (pause) but speaking yes certainly and as far as listening is concerned when they are doing the last 
assignment the seminar presentation may be there it could count (pause) like when students are doing their presentations. (Uma, 13/08/2005)

Wendy, who travelled to remote areas to conduct tutorials using school classrooms hired for the purpose, cited both lack of time and inadequate facilities as a problem.

You can't conduct these listening classes with them because there is this lack of the facilities that you need. The only listening they do is when I talk to them and they write down whatever they can. That's the best they can do. And our time factor because we have to cover six, five to six schools in a day we can't. . . It's quite difficult but we make the most of it. Listening, well we don't have too much of it. Even speaking we don't have too much that really if we do may be $10 \%$. (Wendy, 5/08/2005)

Morgan, who taught at a USP centre, also reported facing similar time constraints.

Well we only have one hour for the tutorial and basically we have group activities and there are times where they are sitting in groups and they exchange ideas, lecture methods but we are not doing much as far as listening is concerned. (Morgan, 6/08/2005)

Thus, the teachers indicated lack of time and facilities, along with limited contact with the learners, as detrimental to their teaching the listening skills component of USP's study skills course.

\section{Support Given to Learners}

Study skills teachers reported on their situation in relation to the support provided to USP students studying at a distance and what they personally did to assist their students in developing their listening skills. Support provided for these students studying at a distance, however, differed from centre to centre. Wendy, the tutor based at the Labasa centre in Fiji, travelled to remote areas and outer islands to conduct her tutorials. While in Lautoka, the other centre in Fiji, the students enrolled in the study skills course travelled from nearby towns to attend the tutorials. Similarly, Judy, the tutor based in Vanuatu, conducted tutorials only for those students in Vila area; however, she did not travel to the outer islands to conduct tutorials. Those students who attended centre-based tutorials were the ones the teachers knew better. During the interviews, the teachers tended to focus on those students they had contact with, and thus they tended to describe their experiences based on teaching those students they had actually met.

The remainder of the students - specifically those who did not attend the face-to-face tutorials offered - had no contact with the teachers, because they studied the print and audio-based materials on their own. Teachers made little mention about these students during the interviews. The teachers, however, were very much aware of these student's learning situations: "But we also have those police men posted in these areas. We have agricultural offices, prison officers, army officers, and police men round the region in the police posts" (Wendy, 5/08/2005). "The type of learners, we get the ones who are fresh from the high schools, those working, mature students, I get that range" (Judy, 3/08/2005). 


\section{Distance Teaching}

All study skills teachers interviewed indicated that they knew how distance teaching was carried out at USP. Additionally, all teachers interviewed indicated that they were university graduates, had secondary as well as tertiary teaching experience in the region, and all were experienced L2 teachers. These teachers reported also being aware of the differences in the facilities, opportunities, and resources made available to their students. Perhaps understandably, these teachers' reported experiences varied depending on their location. The centre-based tutors, for example, only conducted face-to-face tutorials, while the teacher based at USP's Suva campus conducted satellite tutorials, had limited email communication with learners, and visited other centres to conduct tutorials. On occasion, learners from the Suva area visited him for consultation. Overall, the study skills teachers interviewed tended to relate their experiences of teaching this course in terms of interaction with those students who came to see them versus those who did not. Those students who had no contact with their teacher, were typically only known by their enrolment identification numbers. These same teachers, however, voiced their concerns about these 'unseen, unheard' students. Nonetheless, they still tended to focus more on their experiences of teaching those students who attended their tutorials - and even then, interaction was reported as lacking.

Wendy, for example, linked the lack of resources and time available for the face-to-face tutorials to the lack of interaction she faced during her tutorial visits.

Very little interaction because the most you can spend is one hour. That's how much they allow us. I try to unload a lot of things and at the end of which they will ask questions but only a few will ask. The other problem too is not many ask questions. They just will practically accept what comes and that is a problem. (Wendy, 5/08/2005)

According to Judy, who was a Pacific Islander herself, this lack of interaction was associated with the perceived passive nature of Pacific learners.

I encourage them to speak actively, but I find that the Melanesian students are very passive listeners, they absorb everything you say, hold on tightly to it, and they don't think around it. So they just sit there and absorb everything that you say. You ask them if they have a question, one or two very brave ones will ask questions. The rest just stick by what you say. (Judy, 3/08/2005)

Sahil, who conducted satellite tutorials, saw distance - in other words the remoteness of students - as a problem:

The distant learners are a different breed of students altogether; you don't get to see them all the time. So you don't get to really form that rapport with them and when you conduct the satellite tutorials there are very little interaction from students. You are one doing most of the talking and when you ask them if there is any question they will ask very few content questions. (Sahil, 27/07/2005) 


\section{Accent and Academic Level}

Judy conducted tutorials for the learners residing in Vila, Vanuatu. The students she taught all had different educational backgrounds and attainment levels. While some students had dropped out of high school after year 10, some were high school graduates. All her students nonetheless had completed USP's pre-degree courses. Moreover, most of her students were mature, some of whom were enrolled in USP's distance Law programme, or in some other USP programme of study. Judy felt that the students she dealt with generally lacked listening skills - fundamental shortcomings that she felt was primarily due to their differing academic attainment levels or difficulties with spoken accents. "Sometimes they probably don't understand because of accent perhaps, depends on who are speaking and just the level of language that we are using, so they don't understand and that is maybe why they can't take notes" (Judy, 3/08/2005).

All study skills teachers interviewed indicated they were aware of listening skills they needed to teach; all indicated that they knew how listening skills should be taught; and all had certain expectations in terms of their students' prerequisite academic skills. There were, however, marked differences in how these teachers were teaching these listening skills in the study skills course. As such, it is logical to assume that the support they provided to learners would differ as well. The next section reports on former students' past experiences of the 'listening skills' component of the study skills course.

\section{Views of the Students}

Themes emerging from the interviews with past learners were: 1) their self-perception of listening skills, and 2) the strategies they used for facilitating listening.

\section{Self-perception of listening skills}

When students were questioned on their own perceptions of listening skills taught, they responded in a variety of ways. Most students tended to answer this question in relation to the study skills course they took. Their responses ranged from "becoming a better listener" to "still developing the skill."

My own listening skills after completing the course I find myself in a better position than before. (Albert, 8/08/2005)

I listened to the cassette on interpreting texts and I am glad because when you interpret text and it is all very complicated and jumbled, I am now able to jot down the points, link ideas. I manage to interpret text and get down basically what it is all about and try not to be overwhelmed by all the big words. (Thelma, $5 / 08 / 2005)$

The next section reports on the strategies students used, as well as what they said they 'did' when they encountered difficulties during listening.

\section{Strategies for Facilitating Listening}

The former students interviewed for this study, tended to talk about their listening strategies within the context of their study skills course, as well as in their everyday experiences of using 
listening skills. Depending on their profession, the students interviewed reported using varying degrees of listening skills. Those who had jobs that required them to interact with others, or who needed to interview people, mentioned their extensive use of listening skills. Those students, who were still enrolled in other courses, indicated that they required these listening skills for these courses.

The learning strategies framework developed by O’Malley and colleagues (1985) was used as a guide to discuss and explore the strategies students use. Metacognitive strategies include advance organisers, selective attention, and self-evaluation (O'Malley \& Chamot, 1990). Cognitive strategies, as discussed in the literature, include repetition, translation, note taking, conceptualisation, inference, elaboration, and clarification (O'Malley, Chamot, \& Kữpper, 1989; Oxford, 1990). Social mediation strategy involves cooperation with peers for information (O’Malley \& Chamot, 1990).

\section{Metacognitive Strategies}

Students have described the strategies they used, and such strategies can be aligned to the four 'metacognitive strategies' described by O'Malley and Chamot (1990): advance organiser; direct attention; comprehension and evaluation; and selective attention.

\section{Advance organiser}

I think before I go to or have to listen to any topic I do a bit of research on the topic and then I listen so that when I am listening I am able to pick out what is important and what's just the additional, so I take down notes at the same time. (Thelma, 5/08/2005)

\section{Directed attention}

I just listen closely, make notes as I am listening to specific or main text, terms and pick up specific words and create an image for what the person is saying. (Albert, 8/08/2005)

\section{Comprehension and evaluation}

When I am listening to someone talking, I pick out what I can remember and what I think is the key point they are trying to say and then later when I sit back by myself I try to analyse and remember or recall. (Jane, 4/08/2005)

\section{Selective attention}

What I learnt was to listen for example like first of all, so I think oh I see that is one of the points then I need to take note of that. And then they say secondly the other point, I take note of that. (Ian, 4/08/2005) 


\section{Cognitive Strategies}

The students interviewed reported that they used a number of cognitive strategies: translation; seeking clarification; repetition; note taking; and visualization.

\section{Translation}

At times I had to translate them in my language to help me understand and follow the words. I used to translate, listen slowly - trying to follow the conversation. (Tevita, 16/08/2005)

\section{Seeking clarification}

If I was given the opportunity I would ask straight after the talking. If I didn't get the time I think I will have to sit back and think. (Jane, 4/08/2005)

As a student, if I face difficulties for instance during satellite tutorials, I go back and request for a copy of the cassette and listen to it again and then I refer to my notes and for sure it helps. (Thelma, 5/08/2005)

\section{Repetition}

When I am not a good listener than I'll go to an empty room, read and repeat until I understand. (Lily, 5/08/2005)

\section{Note-taking}

I can get the main ideas; take down the main points, taking notes. (Albert, $8 / 08 / 2005)$

\section{Visualisation}

I would pick up specific words, create an image for what the person is saying. (Albert, 8/08/2005)

\section{Social Mediation}

Those students who had opportunities - or made the effort - to attend tutorials, or knew other students enrolled in the same course as them, reported that they used social strategies.

\section{Cooperation}

I ask my classmates or the one sitting beside for what the lecturer is saying. (Ian, $4 / 08 / 2005)$

As discussed earlier, while those students interviewed were enrolled in the same distance study skills course, each had different opportunities and facilities available to them. All students enrolled in the study skills course offered at USP's Vanuatu campus, for example, could have 
attended the centre-based and/ or satellite tutorials available in that region. The Vanuatu campus students, therefore, had available to them opportunities to discuss their problems face-to-face with their tutors. These students also practised and delivered their seminar presentations during these sessions. Learners living in Fiji also had access to similar facilities - centre-based tutorials, satellite tutorials, or visiting tutorials offered by USP's Suva campus. Learners from other parts of Vanuatu and those living in remote areas of the other countries that USP serves, however, did not have easy access to such opportunities primarily due to distance involved. Regardless of the differences in the facilities, opportunities, and course materials made available, all students interviewed for this study reported that they were aware of the listening skills taught, and that they use these listening skills and strategies to help in their learning.

The next section discusses the association of these issues with prior research on listening skills.

\section{Discussion}

The interviews reported here of study skills teachers and those former students who had taken study skills courses, revealed four areas associated with 'listening skills:

1) Differences in the views of L2 teachers and L2 students

2) Differences in the L2 teachers' and L2 students' views about learning strategies

3) Differences in the views expressed by L2 researchers and L2 teachers

4) Lack of research examining 'listening skills' taught at a distance

\section{Differences in views of the L2 teachers and L2 students}

The first issue raised in this paper was the apparent differences between L2 teachers' and L2 students' perceptions of listening skills. Hawkey (2006) examined the perceptual differences of teachers and students of language learning in the same classroom setting. Nunan $(1986,2000)$ also discussed the differing expectations held by these two groups. Griffiths and Parr (2001) and O'Malley and colleagues (1985) discuss differences in the perceptions teachers and students have about language learning strategies. Since the 'listening strategies' explored in this study are based on the language learning strategies framework of O’Malley et al. (1985), this framework will be used to examine the strategies teachers and learners reported using. As indicated, the sample of this study comprised 5 teachers and 19 students, all of whom reported differences in views on listening strategies taught and learned. While the study skills teachers expected their students to bring certain baseline skills to the classroom, they also indicated that 'anonymity' created by the distance mode did result in problems. For example, the teachers interviewed indicated that they expected their students to take notes, listen for information, and involve themselves in discussions and queries; the students, on the other hand, did not report these same expectations as being imparted by the teachers.

Nonetheless, all students interviewed had successfully completed the study skills course - with or without their teachers' support - and all indicated that they were aware of what skills they needed to assist and enhance their learning. They also indicated they felt comfortable with the level of independence the distance mode offered them in their learning path. The study skills teachers, on the other hand, felt that their students lacked the skills, that they needed more support, and were 
generally not up to the level necessary, mostly because English was not their first language. During the interviews, however, none of the students discussed these problems associated with the language. Thus, differences in views about skills and expectations can be seen in this study.

\section{Differences in L2 Teachers' and L2 Students' Views on Learning Strategies}

The second 'issue' revealed from this study is that of the reported listening strategies USP students say they use. While USP's study skills teachers reported that they faced limitations in terms of teaching the 'listening skills' component of the study skills course and indicated that they felt the students still lacked needed 'listening skills', the students, on the other hand, reported on the various metacognitive, cognitive, and social mediation strategies they used to develop their listening skills. Data from the student interviews revealed a mixture of the three strategies students reported employing. The study skills teachers, however, indicated little awareness of the strategies that the students themselves reported they were using. Moreover, the students reported using a variety of strategies, even though in most cases they had studied at a distance and mostly in isolation.

\section{Differences in the views of $L 2$ researchers and $L 2$ teachers}

This study confirms earlier research findings examining differences in the views expressed by L2 researchers and L2 teachers. Berne's (1996, 1998) and Mendelsohn's (2001a, 2001b,) studies found that L2 teachers made little use of listening research to inform their teaching L2 courses in classroom settings. These studies also found that the teachers rarely discussed research on listening with their colleagues. Additionally, the teachers rarely spelled out to their students the learning strategies they wanted them to use in the classroom. USP's study skills teachers were found to hold similar views and reaffirm those views expressed by Berne (1996) who found that teachers do not refer to listening research since they believe that such studies do not provide the answers they need for effective teaching in the classrooms. As Mendelsohn (2001b) found, studies conducted by researchers have not reached the classroom, primarily because many of the researchers have never themselves worked in a classroom. According to Mendelsohn, studies should be conducted by the teachers themselves, or by researchers who are actively involved in the classrooms. Even though the study reported here examines a very different 'distance education' situation, at USP the mismatch between researchers' and practitioners' views on theory and practice is manifest.

\section{Lack of research on listening skills taught by distance}

According to Vandergrift (2004), listening skills are difficult to observe in a learning environment and equally difficult to define. Moreover, learning listening skills can be a very stressful experience for students learning a second language simply because they are often unable to process information quickly enough to understand (Goh \& Taib, 2006). Nonetheless, studies on listening skills, whether in terms of 'listening comprehension' (Hadley, 2001; Lund, 1990) or 'listening strategies' used (Goh, 2002; O'Malley \& Chamot, 1990) have been conducted in real classrooms settings, or situations (i.e., tutorials) wherein teachers and students can interact faceto-face. The factor that distinguishes this study from earlier studies is that the students being taught and undergoing the learning process, are enrolled in study skills courses offered at USP by the distance mode. In short, the students that comprise the sample of this study are or were studying remotely and asynchronously. While all these studies looked at factors affecting L2 
students' listening skills, none have specifically examined students' learning listening skills at a distance. Thus, it is logical to suggest that the insights from research conducted in physical classroom settings cannot be fully applied to students learning at a distance. For this reason alone, it remains difficult to compare distance students' experiences of learning listening strategies based on literature garnered from research conducted in physical face-to-face classroom research settings.

\section{Conclusion}

Vandergrift, Goh, Mareschal and Tafaghodtari (2006) have examined the shift of research interest towards listening comprehension. More recent studies have focused on learners' self-reporting of their understanding and awareness of processes involved in listening in a second language. Vandergrift and colleagues (2006) believe that the students' awareness of the strategies used can have a positive influence on their listening development. In this study, students enrolled in USP distance programmes of study showed an awareness of strategies used, while the USP teachers, on the other hand, reported differing views, based primarily on their lack of contact with distance students. This disconnect suggests that USP's teachers, whether they teach in classrooms or at a distance, must strive to become more aware of their students' learning processes. To overcome this apparent mismatch manifest between the views of researchers, classroom teachers, and students, it is suggested the teachers themselves should be encouraged to conduct research in the classrooms.

Previous studies have mostly explored students' enrolled in study skills courses in a face-to-face learning environment or they have looked at students who learnt foreign languages by distance (Doughty \& Long, 2003). According to Boyle (1995), however, very few published reports report on study skills taught by distance. Additionally, most current distance education research studies tend to report on the use of new technology, online learning, multi-media language learning, and regular contact between learners and teachers (Harris, 2003; Harsh and Sadiq, 2002; Strambi \& Bouvet, 2003). There remains, however, a large body of students whose situation demands that they still must study at a distance using traditional approaches to distance education delivery such as is the case of those students enrolled in USP. Due to this lack of comparative literature in the field of distance education on this topic, an attempt was made here to compare the USP research reported here with similar studies conducted in other fields such as 'listening skills' and 'learner strategies.'

\section{Limitations}

This study shed light on a particular group of teachers and students in a particular educational setting. The sample of this study used only a small group of teachers and learners from USP. A larger sample, with more differences in the method of course delivery and learners from other countries served by USP, may have revealed more insights or revealed other perceptual differences. Regardless, the study achieved its objective, by contributing to an understanding of teachers' expectations and learners' perceptions of the listening skills in a distance education setting.

\section{Future Research}

Future research on teachers' expectation and learners' perception of language learning strategies, perhaps, should focus on distance learners due to the explosive growth taking place in this 
educational sector. It would be useful for researchers from universities, like USP, to conduct further research to acquire a better understanding of learners' strategy use, skills awareness, and teachers' views about students who are learning via distance education modes of course delivery. Such research would also help to fill the gap between research and practice, a problem as indicated by Berne (1996), Hawkey (2006), Mendelsohn (2001a), and Nunan (1986), and which has been discussed in this study. The University of the South Pacific serves a vast region in which multi-media, advanced technology, face-to-face learning, and regular contact with learners remains a largely unattainable dream for most students and educators. Reflective revision of all stakeholders' views is therefore necessary, so that those students who study by traditional distance education methods of course delivery are not overlooked or ignored by researchers, teachers, or students.

\section{References}

Anderson, A., \& Lynch, T. (1988). Listening. Oxford: Oxford University Press.

Berne , J. E. (1998). Examining the relationship between L2 listening research, pedagogical theory, and practice. Foreign Language Annals, 31(2), 169-190.

Berne , J. E. (1996). Current Trends in L2 listening Comprehension Research: Are researchers and language instructors on the same wavelength? Minnesota Language Review, 24(3), 610 .

Berne , J. E. (1995). How does varying pre-listening activities affect second language listening comprehension? Hispania, 78(2), 316-329.

Bolabola, C., \& Wah, R. (Eds.) (1995). South Pacific women in distance education. Studies from the countries of the University of the South Pacific. Suva: University of the South Pacific and the Commonwealth of Learning.

Brown, J. I. (1987). Listening - Ubiquitous yet obscure. Journal of the International Listening Association, 1, 3-14.

Boyle, R. (1995). Language Teaching at a Distance: From the first generation model to the third. System, 23(3), 283-294.

Chamot, A. U. (2005). Language Learning Strategy Instruction: Current issues and research. Annual Review of Applied Linguistics, 25, 112-130.

Chamot, A. U., \& El-Dinary, P. B. (1999). Children's learning strategies in immersion classrooms. The Modern Language Journal, 83(3), 319-341.

Doughty, C. J., \& Long, M. H. (2003). Optimal psycholinguistic environments for distance foreign language learning. Language Learning and Technology, 7(3), 50-80.

Dunkel, P. (1991). Listening in the Native and Second/ Foreign Language: Towards an integration of research and practice. TESOL Quarterly, 25(3), 431-457. 
Same Size Doesn't Fit All: Insights from research on listening skills at the University of the South Pacific (USP) Chand

Feyten, C. M. (1991). The Power of Listening Ability: An overlooked dimension in language acquisition. The Modern Language Journal, 75(2), 173-180.

Glaser, B. G., \& Strauss, A. L. (1967). The Discovery of Grounded Lheory: Strategies for qualitative research, New York: Aldine.

Griffiths, C., \& Parr, J. (2001). Language-Learning Strategies: Theory and perception. ELT Journal, 55(3), 247-254.

Goh, C. C. M. (2002). Exploring listening comprehension tactics and their interaction patterns. System, 30, 185-206.

Goh, C., \& Taib, Y. (2006). Metacognitive instruction in listening for young learners. ELT Journal, 60(3), 222-232.

Hadley, O. A. (2001). Teaching language in context. (3rd. edition).Toronto: Heinle \& Heinle.

Harris, V. (2003). Adapting classroom-based strategy instruction to a distance learning context. TESL-EJ, 7(2). Retrieved July 18, 2005 from: http://writing.berkeley.edu/TESLEJ/ej26/a1.html

Harsh, O. K., \& Sadiq, S. M. (2002). Role of Delivery, Course Design and Teacher-Student Interaction: Observations of adult distance education and traditional on- campus education. International Review of Research in Open and Distance Learning, 3(2). Retrieved May 9, 2006 from: http://www.irrodl.org/index.php/irrodl/article/viewArticle/92/171

Hawkey, R. (2006). Teacher and learner perceptions of language learning activity. ELT Journal, $60(3), 242-252$.

Leontiev, A. (1981). Psychology and the language learning process. Oxford: Pergamon.

Lund, R. J. (1990). A taxonomy for teaching second language listening. Foreign Language Annals, 23, 105-115.

Khaldieh, S. A. (2000). Learning strategies and the writing processes of proficient vs. lessproficient learners of Arabic. Foreign Language Annals, 33(5), 522-533.

Khan, V. (2005). LL114:English for Academic Purposes, Introduction and Assignments, Semester 2. Suva: DFL Support Centre, USP.

Map of USP . (n.d.). Map of the University of the South Pacific service area: November 20, 2004 from: http://www.usp.ac.fj/uspnet

Martin, P. Y., \& Turner, B. A. (1986). Grounded theory and organisational research. The Journal of Applied Behavioural Science, 22(2), 141-157.

Mendelsohn, D. J. (2001a). Listening Comprehension: We've come a long way, but.... Contact, 27(2), 33-40. 
Same Size Doesn't Fit All: Insights from research on listening skills at the University of the South Pacific (USP) Chand

Mendelsohn, D. J. (2001b). Teaching is for researchers, too. TESOL Matters, 11(4), Retrieved August 10, 2006 from:

http://www.tesol.org/s tesol/sec document.asp?CID=194\&DID=908

Nunan, D. (1986). Communicative Language Teaching: The learner's view. Paper presented at 1986 RELC Regional Seminar, Singapore . 21-26 April.

Nunan, D. (2000). Seven hypotheses about language teaching and learning. Plenary presentation, 2000 TESOL Convention, Vancouver. 14-18 March.

O’Malley, J. M., \& Chamot, A. U. (1990). Learning strategies in second language acquisition. Cambridge: Cambridge University Press.

O’Malley, J. M, Chamot, A. U., \& Kữpper, L. (1989). Listening comprehension strategies in second language acquisition. Applied Linguistics, 10(4), 418-437.

O’Malley, J. M., Chamot, A. U., Manzanzres, G. S., Kupper, L., \& Russo, R. P. (1985). Learning strategies used by beginning and intermediate ESL students. Language Learning, 35(1), 2146.

Oxford, R. (1990). Language Learning Strategies: What every teacher should know. Rowley MA.: Newbury House.

Oxford , R. (1993). Research update on teaching L2 listening. System, 21(2), 205-211.

Rankin, P. T. (1930). Listening Ability: Its importance, measurement, and development. Chicago Schools Journal, 147-179.

Rost, M. (1990). Listening in language learning. London: Longman.

Rubin, J. (1975). What the "good language learner" can teach us. TESOL Quarterly, 9(1), 41-51.

Rubin, J. (1994). A review of second language listening comprehension research. Modern Language Journal, 78(2), 199-221.

Rubin, J., \& Thompson, I. (1994). How to be a more successful language learner. (2nd. Ed.). Boston: Heinle \& Heinle.

Schumann, F. (1980). Diary of a >anguage Learner: A further analysis. In R. Scarcella \& S. Krashen (Eds.), Research in second language acquisition (pp. 51-57). Rowley, MA.: Newbury House.

Stern, H. H. (1975). What can we learn from the good language learner? Canadian Modern Language Review, 31, 304-318.

Strambi, A., \& Bouvet, E. (2003). Flexibility and Interaction at a Distance: A mixed-mode environment for language learning. Language Learning and Technology, 7(3), 81-102.

Strauss, A. L., \& Corbin, J. M. (1977). Grounded theory in practice. Thousand Oaks, CA.: Sage. 
Same Size Doesn't Fit All: Insights from research on listening skills at the University of the South Pacific (USP)

Chand

Strevens, P. (1978). New orientations in the teaching of English. Oxford: Oxford University Press.

Takeuchi, O. (2003). What Can We Learn from Good Language Learners: A qualitative study in the Japanese foreign language context. System, 31(3), 385-392.

University of the South Pacific. (2004). A vision to the year 2020. Background papers. Suva: The University of the South Pacific.

Vandergrift, L. (1997a). The Comprehension Strategies of Second Language (French) Listeners: A descriptive study. Foreign Language Annals, 30(3), 387-409.

Vandergrift, L. (1997b). The Cinderella of Communication Strategies: Reception strategies in interactive listening. Modern Language Journal, 81(4), 494-505.

Vandergrift, L. (2003). Orchestrating Strategy Use: Towards a model of the skilled L2 listener. Language Learning, 53, 461-494.

Vandergrift, L. (2004). Listening to learn or learning to listen? Annual Review of Applied Linguistics, 24, 3-25.

Vandergrift, L., Goh, C., Mareschal, C., \& Tafaghodtari, M. (2006). The Metacognitive Awareness Listening Questionnaire: Development and validation. Language Learning, 53(3), 431-462. 


\section{Appendix A}

Map of USP Region

USP Member Countries: Cook Islands, Fiji, Kiribati, Marshall Islands, Nauru, Niue, Samoa, Solomon Islands, Tokelau, Tonga, Tuvalu and Vanuatu.

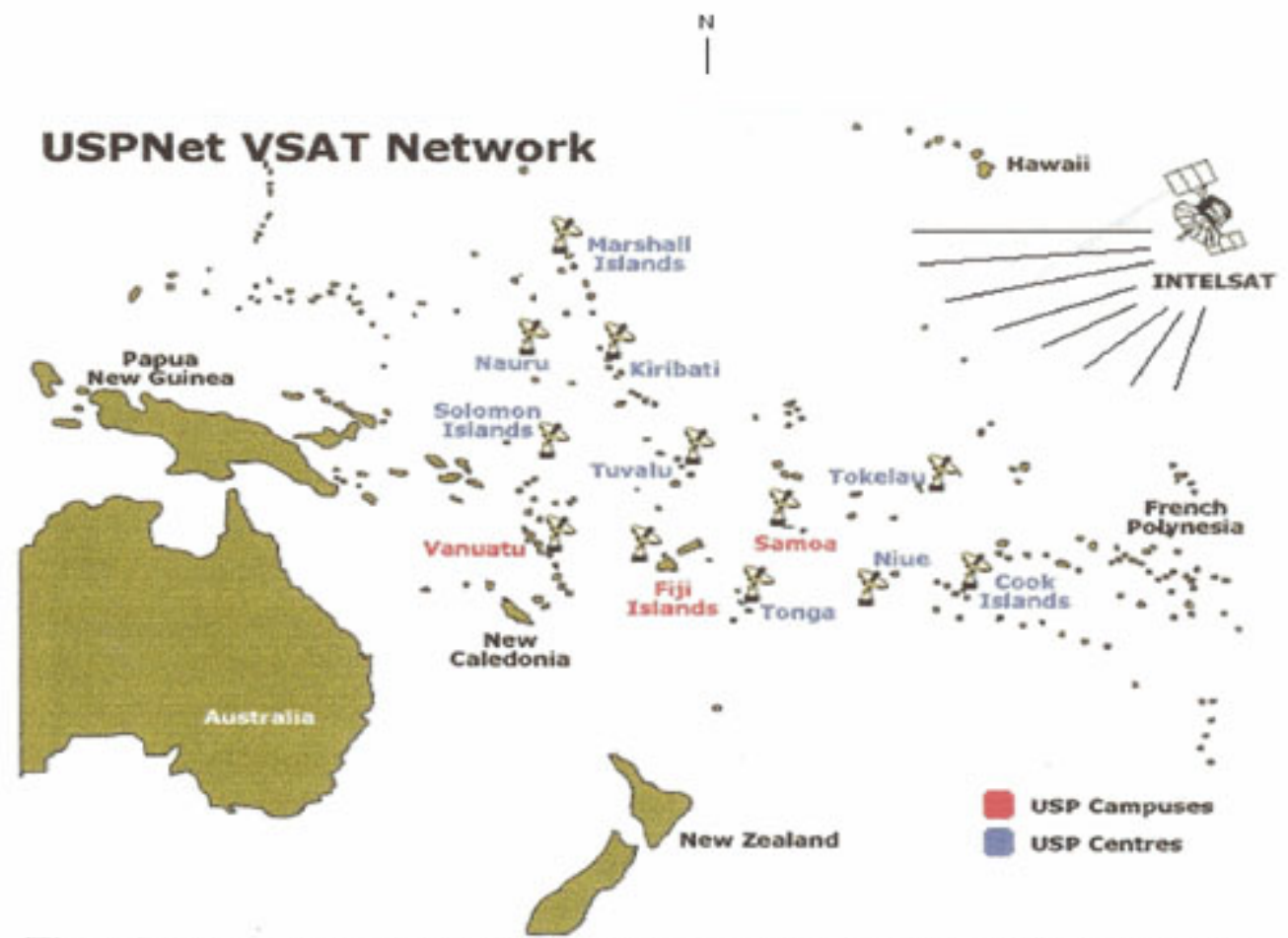

(Fig. 1 shows the location of the various countries and the satellite communication system). 
Same Size Doesn't Fit All: Insights from research on listening skills at the University of the South Pacific (USP) Chand

\section{Appendix B}

Study Skills course, Semester 2, 2005 Schedule

\begin{tabular}{|c|c|c|}
\hline Week No. and date & Unit & Assignments and tutorials \\
\hline 1: 11-15 July & 1: Writing I: Getting started & \\
\hline 2: 18-22 July & $\begin{array}{l}\text { 2: Writing II: Continuing the } \\
\text { process }\end{array}$ & $\begin{array}{l}\text { Satellite tutorial: Thursday } 21 \\
\text { July } 2005-6-7 \mathrm{pm}\end{array}$ \\
\hline 3: 25-29 July & 3: Research & \\
\hline 4: 1-5 August & 4: Rea ding & \\
\hline 5: 8-12 August & $\begin{array}{l}\text { 5: Rea ding and interpreting } \\
\text { texts (Listen to Tape } 1 \text { : } \\
\text { Reading and interpreting text) }\end{array}$ & \\
\hline 6: 15-19 August & $\begin{array}{l}\text { 6: Taking notes from writing } \\
\text { sources }\end{array}$ & $\begin{array}{l}\text { Satellite tutorial: Thursday } 18 \\
\text { August } 2005: 6-7 \mathrm{pm}\end{array}$ \\
\hline 7: 22-26 August & 7: Writing III: Presentation & $\begin{array}{l}\text { Assignment } 1 \text { due: } 26 \text { August } \\
2005\end{array}$ \\
\hline 29 August- 2 September & Mid-Semester Break & \\
\hline 8: 5-9 September & $\begin{array}{l}\text { Mid-Semester Test: } 7 \\
\text { September }\end{array}$ & $5.00 \mathrm{pm}$ local time \\
\hline 9: 12-16 September & 8: Report writing & $\begin{array}{l}\text { Satellite tutorial: Thursday } 15 \\
\text { September 2005: } 6-7 \mathrm{pm}\end{array}$ \\
\hline 10: $19-23$ September & 8: Report writing & \\
\hline $11: 26-30$ September & $\begin{array}{l}\text { 9: Seminar presentation (View } \\
\text { videotape available at USP } \\
\text { Centre). Use the blank tape for } \\
\text { recording your seminar } \\
\text { presentation. }\end{array}$ & \\
\hline $12: 3-7$ October & $\begin{array}{l}\text { 10: Listening to lectures and } \\
\text { taking notes (Listen to Tape } 2 \text { : } \\
\text { Listening to lectures) }\end{array}$ & $\begin{array}{l}\text { Assignment } 2 \text { due: } 3 \text { October } \\
2005 \\
\text { Satellite tutorial: Thursday } 6 \\
\text { October } 2005: 6-7 \mathrm{pm}\end{array}$ \\
\hline 13: $10-14$ October & Revision & $\begin{array}{l}\text { Assignment } 3 \text { due: } 14 \text { October } \\
2005\end{array}$ \\
\hline 14: 17-21 October & Revision & $\begin{array}{l}\text { Satellite tutorial: Thursday } 20 \\
\text { October } 2005: 6-7 \mathrm{pm}\end{array}$ \\
\hline $\begin{array}{l}15: 24-28 \text { October } \\
16: 31 \text { October- } 4 \text { November } \\
17: 7-11 \text { November }\end{array}$ & $\begin{array}{l}\text { Study Break } \\
\text { Examinations: Check with } \\
\text { examination exact time and }\end{array}$ & $\begin{array}{l}\text { your USP Centre for the } \\
\text { date of your }\end{array}$ \\
\hline \multicolumn{3}{|c|}{ Material supplied for the course: } \\
\hline
\end{tabular}


Same Size Doesn't Fit All: Insights from research on listening skills at the University of the South Pacific (USP) Chand

\section{Appendix C}

Details of the teachers of other subjects selected for interview

\begin{tabular}{lllll}
\hline & Name & Gender & $\begin{array}{l}\text { Teaching Experience } \\
\text { (Specifically SST) }\end{array}$ & Location \\
1 & Judy & Female & 10 years & Vila, Vanuatu \\
2 & Morgan & Male & 5 years & Labasa, Fiji \\
3 & Sahil & Male & 4 years & Suva, Fiji \\
4 & Uma & Female & 5 years & Lautoka, Fiji \\
5 & Wendy & Female & 3 years & Labasa, Fiji \\
\hline
\end{tabular}

Details of the past learners selected for the interview

\begin{tabular}{llllll}
\hline & Name & $\begin{array}{l}\text { Place (centre of } \\
\text { enrolment) }\end{array}$ & Gender & Programme & Profession \\
1 & Pravin $\#$ & Suva & Male & $\begin{array}{l}\text { Dip Legal } \\
\text { Studies }\end{array}$ & Prosecution Office \\
2 & Tevita $*$ & Suva & Male & BEd Primary & Teacher \\
3 & Francis * & Suva & Female & Bed Primary & Teacher \\
4 & Vidya $\#$ & Labasa & Female & BA & Domestic Duties \\
5 & Thelma $\#$ & Labasa & Female & LLB & Joumalist/student \\
6 & Priya & Labasa & Female & BA GCE & Student \\
7 & Una & Labasa & Female & BEd & Student \\
8 & Lote & Labasa & Female & BA & Student \\
9 & Kamal & Lautoka & Female & BA GCE & Student \\
10 & Nisha & Lautoka & Female & BA & Student \\
11 & Nita $\#$ & Lautoka & Female & BEd & Teacher \\
12 & Sheena $\#$ & Lautoka & Female & BEd & Teacher \\
13 & Kumar $\#$ & Lautoka & Male & BEd & Teacher \\
14 & Jane & Vila, Vanuatu & Female & BA & Library \\
& & & & & Assistant/student \\
15 & Albert & Vila, Vanuatu & Male & LLB & Student \\
16 & Martin & Vila, Vanuatu & Male & LLB & Student \\
17 & Ian & Vila, Vanuatu & Male & MBBS & Student \\
18 & Leni & Vila, Vanuatu & Male & LLB & Church \\
& & & & & Minister/student \\
19 & Luke & Vila, Vanuatu & Male & LLB & Student \\
\hline
\end{tabular}

Note: * could not get to tutorial ses sions because of distance

\# could not attend all tutorial sessions due to work commitments

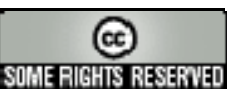

